\title{
Study of Various Hematological Parameters and Iron Status among Voluntary Blood Donors
}

\author{
Hemali Jayantilal Tailor ${ }^{1}$, Prashant Ramanbhai Patel, ${ }^{2}$ Amrish Kumar Narhari Prasad Pandya, ${ }^{3}$ Sarita Mangukiya
}

\section{Hemali Jayantilal Tailor', ${ }^{1}$ Prashant Ramanbhai Pa- tel, ${ }^{2}$ Amrish kumar Narhari prasad pandya, ${ }^{3}$ Sarita Mangukiya}

\section{${ }^{1}$ Associate Professor, Department of Pathology, Baroda Medical College, Baroda, Gujarat, India. \\ ${ }^{2}$ Professor, Department of IHBT, Government Medical College, Surat, Gujarat, India. \\ ${ }^{3}$ Tutor, Department of Biochemistry, Government Medical College, Surat, Gujarat, India.}

*'These authors contributed equally to this work."

\section{Correspondence}

Dr. Hemali Jayantilal Tailor

60, Sai Samarpan Society, Bamroli Road, Udhna, Surat. 394210, Gujarat, India. Mob. 9925034366

E-mail address: hamsanp@yahoo.co.in

\section{History}

- Submission Date: 11-04-2016

- Revision Date : 15-12-2016

- Accepted Date: 17-01-2017

DOI : 10.5530/ijmedph.2017.1.11

\section{Article Available online}

http://www.ijmedph.org/v7/i1

\section{Copyright}

(C) 2017 Phcog.Net. This is an openaccess article distributed under the terms of the Creative Commons Attribution 4.0 International license.

\begin{abstract}
Introduction: Iron deficiency is a complication of regular blood donation. To recruit and retain regular voluntary blood donors, the iron status of the donors needs to be identified. Objective: The present study was done using a combination of hematological and iron status parameters to detect prevalence of iron deficiency anaemia in the voluntary blood donors. Method: Complete blood count was performed on three part hematology analyzer and serum ferritin was measured by standard enzyme immunoassay technique on 393 random voluntary blood donor samples. Ferritin values below $15 \mu \mathrm{g} / \mathrm{L}$ were considered iron deficient, $15-20$ borderline, and above 20 normal. Results: Out of 393 donors, 111 first time and 282 repeat donors. The repeat donors were subdivided into different subgroups like as per their last donation into group I to IV, and as per their frequency of donation into group A to D. First time donors had higher mean serum ferritin levels than that in repeat donors. $28.5 \%$ of blood donors had depleted iron stores (serum ferritin $<20 \mu \mathrm{g} / \mathrm{L}$ ) and $19.6 \%$ of donors were anemic. Serum ferritin was markedly reduced in donors $>20$ time donation frequency and last donation within 3-5 months. Conclusion: There was a significant correlation between the frequency of donations, last donation interval and the serum ferritin measurement so it should be included in the assessment of regular blood donors to secure adequate iron reserves in the donor population and there is a need to modify the donor acceptance criteria.
\end{abstract}

Key words: Iron deficiency, Blood Donation, Hematological Parameters, Serum Ferritin.

\section{INTRODUCTION}

The voluntary unpaid blood donation is a humanitarian act towards the sick by the healthy. No transfusion service can survive without blood donors. The wellbeing and health of the blood donors is of prime importance for the medical profession. A lot has been discovered and written about protection of the recipients from the potential hazards of blood transfusion. A lot of money is being spent for the screening of donors for protection of recipients but very little attention is given to the health status of donors. The main reason is the fear of losing the donor in a time when the demand of blood is soaring all over the world and the donors are becoming scarce. ${ }^{1}$

Chronic iron deficiency is a well-recognized complication of regular blood donation. ${ }^{2,3}$ After a single donation, a person needs approximately 3 months to replenish iron stores. ${ }^{4}$ In the majority of blood banks, hemoglobin ( $\mathrm{Hb})$ measurement is used as a screening test for the ability to donate blood. Since hemoglobin levels may be normal in the presence of reduced iron stores. ${ }^{5,6}$ The use of this parameter has been reported to have poor sensitivity in the detection of early stages of iron deficiency. ${ }^{1}$

Indeed, an accurate diagnosis of a state of iron deficiency requires several laboratory tests. Measurements of serum ferritin concentrations and red cell indices such as mean cell volume (MCV) and mean corpuscular haemoglobin $(\mathrm{MCH})$ can be used with a high degree of accuracy and precision. ${ }^{7,8}$ Previous studies have shown that the serum ferritin levels were reduced markedly in regular donors corresponding to annual donation frequency. 5,9

In order to fulfill the global and national drive to recruit and retain regular repeat voluntary blood donors, the iron status of the donors needs to be identified and necessary steps for iron supplementation need to be taken. There is paucity of data in India country, particularly in and around Surat city regarding impact of regular voluntary blood donation on iron status of donors. The present study was, therefore, designed to assess (using a combination of hematological and iron status parameters) the development of anaemia and prevalence of iron deficiency anaemia in the voluntary blood donors in Surat city donors.

\section{MATERIAL AND METHOD:}

Total 393 random voluntary blood donor samples were collected from June 2012 to February 2014, out of which 384 were males and 9 were female donors. The samples were tested for various tests to evaluate the iron status of the donors. The selected donors 
were asked specific questions as per donor questionnaire, i.e., age, total number of life time donations, date of last donation/previous donation. Each donor donated $300-450 \mathrm{~mL}$ of whole blood depending on their body weight.

After blood donation of whole blood, an additional sample was taken via the bleed line into a $2.5 \mathrm{~mL}$ EDTA tube for assays of complete blood count, and into $4.0 \mathrm{~mL}$ plain tubes for measurement of serum ferritin. Complete blood count was performed on three part hematology analyzer and serum ferritin was measured by standard enzyme immunoassay technique. The assays were validated using appropriate controls for each lot used.

Data were analyzed in excel sheet and using statistical computer software SPSS. Comparisons between populations were made using various statistical tests. Ferritin values below $15 \mu \mathrm{g} / \mathrm{L}$ were considered iron deficient, 15- 20 borderline, and above 20 normal. Hemoglobin values below $12.5 \mathrm{~g} / \mathrm{dl}$ were considered to represent anemia.

\section{RESULTS}

Out of total 393 donors, 111 donors donated for the first time and 282 donors were donated more than once. The donors were in between 18 and 58 years of age. Most of the donors (43.77\%) were in between the age group of 21 to 30 years followed by 31 to 40 years of age groups (28.24\%).

The eligible donors were divided into two main groups like first time donors and repeat donors. The second repeat donor group was subdivided into different subgroups like as per their last donation into group I to IV, and as per their frequency of donation into group A to D.
Table 2 shows the mean $\mathrm{Hb}$ level was high in first time donor group compared to repeat donor group. The $\mathrm{MCV}$ and $\mathrm{MCH}$ value in repeat donors were low compared to first time donors but mean of RBC count was more in repeat donors. Serum ferritin was markedly reduced in repeat donors.

Table 3 shows in repeat donors all the stages of iron depletion, iron deficient erythropoiesis and iron deficiency anemia were more prevalent compared to first time donors.

Table 4 shows negative iron balance, iron deficient erythropoiesis and iron deficiency anemia were most common in first group which was last donation between 3-5 months interval followed by group 2 . The last group did not show any donor with iron deficiency. The data showed significant impact of donation interval on iron status.

Table 5 shows that negative iron balance was more common in first group which was the frequency of donation 1-5 times followed by group B (6-10 times). Iron deficient erythropoiesis was more common in group with $>20$ times donation frequency followed by 11-20 times. Iron deficiency anemia was more common in donation frequency $>20$ times and group B which was 6-10 times donation frequency, that may be because the reason that the maximum number of group B donated within six months of last donation interval. The data finally conclude that as the donation frequency increases the chances of developing iron deficiency increases.

Table 6 shows serum ferritin was markedly reduced in repeat donors having last donation 3-5 months.

Table 7 shows serum ferritin was markedly reduced in repeat donors group D with > 20 time donation frequency.

Table 1: Repeat donor subgroup distribution

\begin{tabular}{cccccc} 
DONORS & $\begin{array}{c}\text { GROUP I } \\
\text { 3-5 MONTHS }\end{array}$ & $\begin{array}{c}\text { GROUP II } \\
\text { 6-9 MONTHS }\end{array}$ & $\begin{array}{c}\text { GROUP III 10 - 20 } \\
\text { MONTHS }\end{array}$ & $\begin{array}{c}\text { GROUP IV > 20 } \\
\text { MONTHS }\end{array}$ & TOTAL \\
\hline GROUP A [1-5 TIMES] & 42 & 52 & 25 & 6 & 125 \\
GROUP B [ 6-10 TIMES] & 28 & 42 & 12 & 2 & 84 \\
GROUP C [11-20 TIMES] & 12 & 25 & 7 & 1 & 45 \\
GROUP D [>20 TIMES] & 12 & 15 & 1 & 0 & 28 \\
TOTAL & 94 & 134 & 45 & 9 & 282
\end{tabular}

Table 2: Mean and SD value of different parameters in first time donors and repeat donors

\begin{tabular}{|c|c|c|c|c|c|}
\hline \multirow{2}{*}{$\begin{array}{l}\text { PARAMETER } \\
\text { AGE[years] }\end{array}$} & \multicolumn{2}{|c|}{$\begin{array}{c}\text { FIRST TIME } \\
\text { DONORS } \\
\mathrm{N}=111\end{array}$} & \multicolumn{2}{|c|}{ 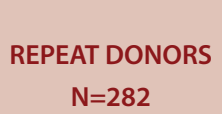 } & \multirow{2}{*}{$\begin{array}{c}\text { PVALUE } \\
-\end{array}$} \\
\hline & 26.9 & \pm 7.26 & 33.17 & \pm 8.82 & \\
\hline $\mathrm{Hb}[\mathrm{g} / \mathrm{dl}]$ & 13.58 & \pm 1.37 & 13.15 & \pm 1.32 & $<0.05$ \\
\hline $\mathrm{MCV}[\mathrm{fl}]$ & 89.15 & \pm 7.10 & 85.17 & \pm 7.15 & $<0.001$ \\
\hline $\mathrm{MCH}[\mathrm{pg}]$ & 29.28 & \pm 2.88 & 28.05 & \pm 3.04 & $<0.001$ \\
\hline $\mathrm{RBC}[$ millions/cmm] & 4.67 & \pm 0.59 & 4.85 & \pm 0.56 & $<0.05$ \\
\hline SERUM FERRITIN $[\mu \mathrm{g} / \mathrm{l}]$ & 85.81 & \pm 68.19 & 44.88 & \pm 56.51 & $<0.001$ \\
\hline
\end{tabular}

Table 3: First time and repeat donors distribution according to iron deficiency stages

$\begin{array}{cccc}\text { Criteria } & \text { First time donors } & \text { Repeat donors } & \text { P value } \\ \text { No. of donors } & 111 & 282 & - \\ \text { Negative Iron Balance [Ferritin }<20 \mu \mathrm{g} / \mathrm{l} \mathrm{But} \geq 15 \mu \mathrm{g} / \mathrm{l}] & 2[1.80 \%] & 14[4.96 \%] & 0.1533 \\ \text { Iron deficient erythropoiesis [ferritin }<15 \mu \mathrm{g} / \mathrm{l} @ \text { normal } \mathrm{Hb}] & 2[1.80 \%] & 65[23.05 \%] & <0.001 \\ \text { Iron deficiency anemia [ferritin }<15 \mu \mathrm{g} / \mathrm{l} \& \mathrm{Hb}<12.5 \mathrm{~g} / \mathrm{dl}] & 1[0.90 \%] & 28[9.93 \%] & <0.05\end{array}$


Table 4: Iron deficiency stages in repeat donor groups as per last donation.

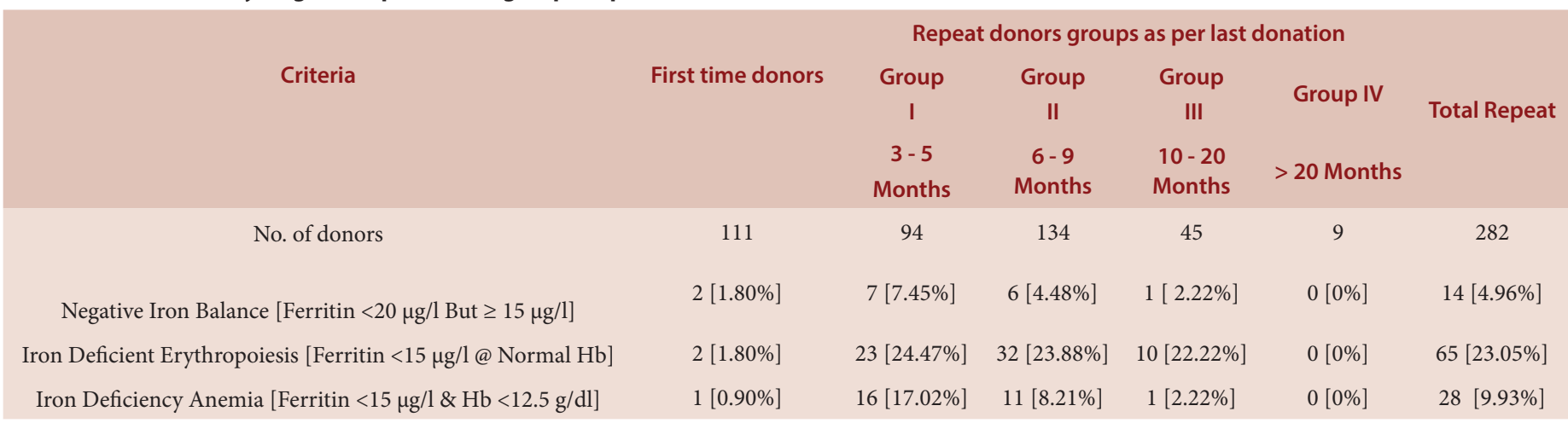

Table 5: Iron deficiency stages in repeat donor groups as per frequency of donation

\begin{tabular}{|c|c|c|c|c|c|c|}
\hline \multirow{4}{*}{ Criteria } & \multicolumn{6}{|c|}{ Repeat donors groups as per frequency of donation } \\
\hline & $\begin{array}{c}\text { First time } \\
\text { donors }\end{array}$ & Group & Group & Group & Group & \\
\hline & & A & B & C & D & Total repeat \\
\hline & & $\begin{array}{l}1-5 \\
\text { Times }\end{array}$ & $\begin{array}{l}6-10 \\
\text { Times }\end{array}$ & $11-20$ Times & > 20 Times & \\
\hline No. of donors & 111 & 125 & 84 & 45 & 28 & 282 \\
\hline $\begin{array}{c}\text { Negative Iron Balance } \\
{[\text { Ferritin }<20 \mu \mathrm{g} / \mathrm{l} \text { But } \geq 15 \mu \mathrm{g} / \mathrm{l}]}\end{array}$ & $2[1.80 \%]$ & $8[6.40 \%]$ & $4[4.76 \%]$ & $2[4.44 \%]$ & $0[0 \%]$ & 14 [4.96\%] \\
\hline 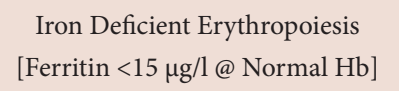 & $2[1.80 \%]$ & $30[24 \%]$ & $15[17.86 \%]$ & $11[24.44 \%]$ & $9[32.14 \%]$ & $65[23.05 \%]$ \\
\hline $\begin{array}{c}\text { Iron Deficiency Anemia } \\
{[\text { Ferritin }<15 \mu \mathrm{g} / \mathrm{l} \& \mathrm{Hb}<12.5 \mathrm{~g} / \mathrm{dl}]}\end{array}$ & $1[0.90 \%]$ & $8[6.40 \%]$ & $12[14.29 \%]$ & $4[8.89 \%]$ & 4 [14.29\%] & 28 [9.93\%] \\
\hline
\end{tabular}

Table 6: Mean value serum ferritin in different groups as per last donation.

\begin{tabular}{ccccccc} 
parameter & $\begin{array}{c}\text { First time } \\
\text { donors }\end{array}$ & \multicolumn{2}{c}{ Mean value of repeat donors as per last donation } \\
& & Group- I & Group - II & Group - III & Group - IV & P value \\
No. of donors & 111 & $3-5$ Months & 6-9 Months & $10-20$ Months & $>$ 20 Months & \\
Serum Ferritin $[\mu \mathrm{g} / \mathrm{l}]$ & $85.81 \pm 68.19$ & $36.85 \pm 54.92$ & $41.43 \pm 45.35$ & $58.94 \pm 63.44$ & $109.57 \pm 117.73$ & $<0.001$ \\
\hline
\end{tabular}

Table 7: Mean value serum ferritin in different groups as per frequency of donation

\begin{tabular}{|c|c|c|c|c|c|c|}
\hline \multirow{4}{*}{ Parameter } & \multirow{4}{*}{ First time donors } & \multicolumn{4}{|c|}{ Mean value of repeat donors as per frequency of donation } & \multirow{4}{*}{ P value } \\
\hline & & Group & Group & Group & Group & \\
\hline & & A & B & C & D & \\
\hline & & $\begin{array}{c}1 \text { - } 5 \\
\text { Times }\end{array}$ & $6-10$ Times & 11 - 20 Times & $>20$ Times & \\
\hline No. of Donors & 111 & 125 & 84 & 45 & 28 & - \\
\hline Serum Ferritin $[\mu \mathrm{g} / 1]$ & $85.81 \pm 68.19$ & $48.93 \pm 64.47$ & $43.76 \pm 54.42$ & $39.52 \pm 38.93$ & $38.58 \pm 48.4$ & $<0.001$ \\
\hline
\end{tabular}

\section{DISCUSSION}

Although several studies have indicated that repeated blood donation induces iron depletion and iron deficiency, all blood centers still test only hemoglobin as an indicator for selecting the donors. ${ }^{2}$ The present study which was done by testing various parameters such as hemoglobin, RBC indices, and serum ferritin levels, showed the importance of measuring the iron stores and then proposed a strategy to prevent severe iron depletion during frequent donations.

The potential for an individual donor to give blood without developing iron-deficiency anaemia is dependent on many factors such as differences in nutritional iron intake, the prevalence of iron deficiency in the particular population, menstrual iron loss in females, the frequency of 
blood donation, the use of supplemental iron, as well as the capacity to absorb iron..$^{6,10}$

Blood banks should have the responsibility to protect blood donors, which includes preventing anaemia among them. Several studies indicate that hemoglobin is not a sensitive indicator to detect iron deficiency but is useful in detecting the majority of donors with established iron deficiency. ${ }^{10}$

Recruiting a sufficient number of new blood donors is a huge challenge in many countries. ${ }^{11,12}$ One of the main reasons for rejection was failing to meet the $\mathrm{Hb}$ criteria, predominantly amongst young women. ${ }^{13}$ To keep the blood supply sufficient, an increased pressure is laid upon established donors. The donors with a high frequency of donations are at risk for iron deficiency.

Mittal R. has shown the extent of iron deficiency in our so called healthy blood donor population. ${ }^{2}$ Though others have also shown the extent of iron deficiency in regular blood donors, 50 per cent of healthy females were iron deficient even before donation. ${ }^{14}$

In the present study mean ferritin concentration of $85.81 \mu \mathrm{g} / \mathrm{L}$ in first time donors was significantly higher than the mean value of $44.88 \mu \mathrm{g} / \mathrm{L}$ among repeat blood donors. In female donors the mean ferritin concentration was $32.16 \mu \mathrm{g} / \mathrm{L}$ and that of male donors was $57.04 \mu \mathrm{g} / \mathrm{L}$. This finding was consistent with the results of other studies in which serum ferritin levels were significantly lower in regular blood donors. ${ }^{5,14}$ The results of this study showed that $28.5 \%$ of blood donors had depleted iron stores (serum ferritin $<20 \mu \mathrm{g} / \mathrm{L}$ ) and $19.6 \%$ of donors were anemic $(\mathrm{Hb}<12.5 \mathrm{~g} / \mathrm{dl})$. Our study indicated that there was a significant correlation between the frequency of donations, last donation interval and the serum ferritin level.

Alvarez-Ossorio et al recommend measurements of serum ferritin levels after five donations. This will help identify iron deficient individuals. One of the most frequent observations in long-term blood donors is chronic iron deficiency. ${ }^{5,10}$ Early detection of iron deficiency among blood donors would allow appropriate readjustment of donation intervals and would guide the use of iron supplementation. It has recently been recommended that short-term iron supplementation combined with adjustments of hemoglobin acceptance levels may reduce the rate of donor deferral for low hemoglobin. ${ }^{15}$

The reason for iron deficiency in donors with repeated donations is that the iron demands increase with number of annual blood donations. Even though the absorption of nutritional iron among donors is much more efficient than non-donors, a donation frequency of 4-5 units per year cannot be compensated by iron absorption and results in an iron deficiency. ${ }^{10,16}$

Rosvik AS suggested the need for a better administration of iron supplementation to blood donors according to their serum ferritin values. Measurements of serum ferritin once a year is needed to supervise the iron supplementation. Donors with pre donation serum ferritin $<50 \mu \mathrm{g} / \mathrm{L}$ should be offered iron after donation, while donors with serum ferritin $>$ $80 \mu \mathrm{g} / \mathrm{L}$ do not need additional iron. Donors with serum ferritin between these limits must be judged individually. Measurements of serum ferritin regularly can detect iron overload. If iron overload is present, it will be considered malpractice to provide iron supplementation. ${ }^{[17]}$

In conclusion, hemoglobin estimation alone may not be enough to evaluate donor safety prior to phlebotomy. In our country, the iron stores in females are low especially in the reproductive age group. Hence, serum ferritin evaluation needs to be included in the testing of first time female donors for donor safety.

Plasma ferritin has been used to diagnose IDA because the ferritin level is considered to be the single, most powerful test for its diagnosis. ${ }^{18}$ Ferritin is independent of external contamination of blood samples, diurnal variation, and concurrent iron therapy. Even though plasma ferritin is an acute phase reactant that can be elevated in various inflammatory conditions, as this study group comprised of healthy donor population, the probability of inflammation was negligible. For diagnosis of IDA, plasma ferritin threshold of $15 \mu \mathrm{g} / 1$ was used in this study, as suggested by Susan. ${ }^{19}$

Considering the findings in this and other studies, what measures blood collectors should pursue to address iron depletion? There is no single answer, but several approaches should be considered: 1) modifying the donor $\mathrm{Hb}$ requirements and measurement of $\mathrm{Hb}, 2$ ) changing the inter donation interval, 3) testing for serum ferritin, and 4) iron supplementation. ${ }^{20}$ One way is to take national initiative to reduce the magnitude of iron deficiency in our population by education, behavioral changes in the area of food habits and iron supplementation. ${ }^{21}$

Educating the donor about iron rich food is easy but takes time. Hence, it is difficult for a busy blood bank to spare the time for such education. However, it is possible to create various educative materials to improve iron uptake through dietary modifications but the effect of this to change the nature of food intake, may be marginal. Supplementing iron tablets to regular donors can be thought. Oral iron is known to produce gastrointestinal side effects hence unlikely to be accepted by healthy donors even if it is given free from blood banks However, in India a significant proportion of our population has haemoglobinopathy genes which on iron supplementation may cause iron overload. The ideal solution would be education and supplementation of iron coupled with haemoglobinopathy control programme. A majority of Indians are vegetarian that results in poor absorption of iron from the food. Reduction of frequency of donation from 3-4 times a year to twice a year may bring down the proportion of donors who become iron deficient after a few years of regular transfusion.

Finally, screening the donors by serum ferritin levels at the time of first donation and subsequently once every year becomes very rational for voluntary blood donation programme avoiding iron deficiency in donor population. In fact, ferritin assay costs extra financial burden but this gives us value for money by generating national data on prevalence of iron deficiency, treating the iron deficient donor, referring the donor for further medical investigation and treatment if donor remains persistently iron deficient in spite of compliant oral iron intake. Donors will also feel that they are given extra care for the service they are doing. ${ }^{22}$

\section{CONCLUSION}

Blood donation has a profound influence on iron stores and is a very important factor for iron deficiency in blood donors, particularly in multi-time donors and, especially in female donors despite these donors being eligible to give blood according to the current guidelines (haemoglobin $>12.5 \mathrm{~g} / \mathrm{dL}$ ). It may, therefore, be necessary to review the screening criteria used at the time of donation. It also seems logical to include serum ferritin measurement in the assessment of regular blood donors to secure adequate iron reserves in the donor population in order to maintain an appropriate donation potential

\section{ACKNOWLEDGEMENT}

None

\section{CONFLICT OF INTEREST}

\section{None}




\section{ABBREVIATIONS USED}

Hb: Hemoglobin; MCV: Mean corpuscular volume; MCH: Mean corpuscular hemoglobin; EDTA: Ethylenediaminetetraacetic acid; IDA: Iron deficiency anemia.

\section{REFERENCES}

1. Ali AM, Mc Avoy AT, Ali MA et al. An approach to determine objectively minimum hemoglobin standards for blood donors. Transfusion 1985;25(3):286-8. https:// doi.org/10.1046/j.1537-2995.1985.25385219919.x PMid:4002317.

2. Mittal R, Marwaha N, Basu S, Mohan H, Ravikumar A. Evaluation of iron stores in blood donors by serum ferritin. Indian Journal of Med Res. 2006;124(6):641-6. PMid:17287551.

3. Simon TL. Iron, iron everywhere but not enough to donate. Transfusion 2002;42(6):664-5. https://doi.org/10.1046/j.1537-2995.2002.00121.x; PMid:12147015.

4. Skikne B, Lynch S, Borek D, Cook J. Iron and blood donation. Clinics in Haematology. 1984;13:271-7. PMid:6373083.

5. Alvarez-Ossorio L, Kirchner H, Kluter H, Schlenke P. Low ferritin levels indicate the need for iron supplementation: strategy to minimize iron-depletion in regular blood donors. Transfusion Med. 2000;10(2):107-12. https://doi.org/10.1046/ j.1365-3148.2000.00239.x.

6. Milman N, Sondergard M. Iron stores in male blood donors evaluated by serum ferritin. Transfusion 1984:24(6):464-8. https://doi.org/10.1046/j.15372995.1984.24685066801.x ; PMid:6506174

7. Røsvik AS, Ulvik RJ, Wentzel-Larsen T, Hervig T. The effect of blood donation frequency on iron status. Transfus Apher Sci 2009;41(3):165-9. https://doi. org/10.1016/j.transci.2009.09.017; PMid:19819187.

8. Nadarajan V, Sthaneshwar P, Eow GI. Use of red blood cell indices for the identification of iron deficiency among blood donors. Transfus Med 2008:18(3):184-9. https://doi.org/10.1111/j.1365-3148.2008.00862.x ; PMid:18598281.

9. Milman N, Ovesen L, Byg KE, Graudal N. Iron status in Danes updated 1994. I: Prevelence of iron deficiency and iron overload in 1332 men aged 40-70 years. Influence of blood donation, alcohol intake, and iron supplementation. Ann Hematol 1999;78(9):393-400. https://doi.org/10.1007/s002770050537; PMid:10525826.

10. Simon TL, Garry PJ, Hooper EM. Iron stores in blood donors. J Am Med
Assoc 1981;245(20):2038-43. https://doi.org/10.1001/jama.1981.03310450030018: https://doi.org/10.1001/jama.245.20.2038.

11. Misje $A H$, Bosnes $V$, Heier HE. Recruiting and retaining young people as voluntary blood donors. Vox Sang. 2008;94(2):119-24. https://doi.org/10.1111/j.14230410.2007.01004.x; PMid:18067488.

12. Custer B, Johnson ES, Sullivan SD, Hazlet TK, Ramsey SD, Hirschler NV Murphy EL, Busch MP. Quantifying losses to the donated blood supply due to donor deferral and mis collection. Transfusion 2004:44(10):1417-26. https://doi. org/10.1111/j.1537-2995.2004.04160.x; PMid:15383013.

13. Rosvik AS, Hervig T, Wentzel-Larsen T, Ulvik RJ. Iron status in Norwegian blood donors: comparison of iron status in new blood donors registered in 1993-1997 and in2005-2006. Vox Sang. 2009;96(1):49-55. https://doi.org/10.1111/j.14230410.2008.01115.x; PMid:19121198.

14. Nadarajan VS, Eow GI. Anaemia and iron among blood donors in a blood transfusion unit in Malaysia. Malaysian J Pathol 2002;24(2):99-102. PMid:12887168.

15. Newman B. Iron depletion by whole-blood donation harms menstruating females: the current whole-blood collection paradigm needs to be changed. Transfusion 2006;46(10):1667-81. https://doi.org/10.1111/j.15372995.2006.00969.x ; PMid:17002622.

16. Garry PJ, Koehler KM, Simon TL. Iron stores and iron absorption: effects of repeated blood donations. Am J Clin Nutr 1995;62(3):611-20. PMid:7661124.

17. Røsvik AS. Iron status in Norwegian blood donors: comparison of iron status in new blood donors registered in 1993-1997 and in 2005-2006. Vox Sang. 2009;96(1):49-55. https://doi.org/10.1111/j.1423-0410.2008.01115.x; PMid:19121198.

18. Guyatt GH, Oxman AD, Ali M, Willan A, Mcllroy W, Patterson C. Laboratory diagnosis of iron-deficiency anemia: An overview. J Gen Intern Med 1992;7(2):145-53. https://doi.org/10.1007/BF02598003; PMid:1487761.

19. Clark SF. Iron Deficiency Anemia. Nutrition in Clinical Practice 2008:23:128-41. https://doi.org/10.1177/0884533608314536; PMid:18390780.

20. Rodolfo DC, Dante LJ. Blood donation, blood supply, iron deficiency and anemia It is time to shift attention back to donor health. Rev Bras Hematol Hemoter. 2012;34(5):323-33.

21. Narsinga R BS. Anaemia and micronutrient deficiency. Natl Med J India 2003; 16:46-50.

22. Ghosh K. Iron deficiency in healthy blood donors exposes vulnerability of the nation to iron deficiency Commentary, Indian J Med Res. 2006;124(6):611-2. PMid:17287547.

Cite this article : Tailor HJ, Patel PR, Pandya AN, Mangukiya S. Study of various hematological parameters and iron status among voluntary blood donors. Int J Med. Public Health. 2017; 7(1): 61-5. 